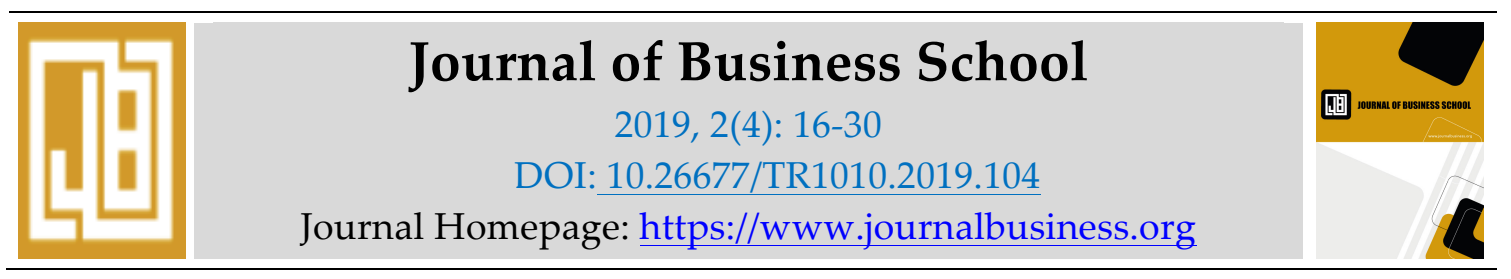

\title{
The Growth Stimulating Role of Economic Globalization on Emerging Countries in Africa: Nigeria in Perspective
}

\author{
Dumani Markjackson \\ Department of Banking and Finance, Federal Polytechnic, Ekowe, PMB 110, Yenagoa, \\ Bayelsa State, Nigeria. abinami1990@gmail.com
}

\begin{abstract}
This study was carried out due to the varied views on the impact of economic globalization on economic growth in emerging countries. Some scholars are of the view that economic globalization intensify economic growth based on empirical findings and theoretical conjectures; others, albeit, in the minority, hold the view that it increases the gap between the haves and the have not's between countries. Thus, this study observed these positions and specifically examined the impact of foreign direct investment on agriculture and manufacturing sectors plus the degree of trade openness on real gross domestic product from 1981 to 2016 in Nigeria. Secondary time series data was collated for the analysis and estimation. The ex-post facto research design was adopted to explain the impact of the explanatory variables on the dependent variable in retrospect. The Augmented Dickey Fuller test was employed to solidify the series, which integrated at first difference, Johansen co-integration test for the long run relationship, which reported two long run equilibrium relationship, and the error correction technique for the estimation of the model were adopted. The empirical findings reveal that the measures of capital inflow and trade have a positive and significant impact on economic growth in Nigeria. This study, therefore, offers additional credence to the role economic globalization plays in economic growth. The study suggests that measures should be taken to encourage production of goods in which the nation has comparative and competitive advantage over its trading partners and stabilization policies be implemented to encourage investment sustainability.
\end{abstract}

Keywords: Foreign direct investments, degree of trade openness, economic globalization, Nigeria

\section{Introduction}

There is no generally agreed definition of globalisation in economic literature (Alimi \& Atanda, 2011). This is understandable because globalisation covers almost all spheres of human endeavour. Thus, every definition of the subject depends on the perspective of the writer. To this end, the World Trade organisation (WTO) in 2008 summed these numerous definitions of globalisation to mean "the integration of capital, investment and labour markets or its integration with world markets." This implies that globalisation makes the world into a unit 
called the "global village" where information and factors of production (like labour, capital and entrepreneurs) can interact almost free of charge irrespective of geographical boundaries. In technical economic sense, this creates more advantages and opportunities for countries who are wholly involved in it. Thus, proponents of economic growth believe that the no border economic configuration breeds economic growth via external trade, interconnect of financial markets and systems, mobility of labour and technical know-how (Kilic, 2015).

Consequently, the argument for the need for globalisation started squares of years ago. Specifically, it started five decades before World War I (Wan-Wen, n.d). Notwithstanding, between World I and World II, the dependency theorists (who advocate for developing countries not to join foreign markets due to the perceived innate threats and disadvantages) and the revisionist who questioned and challenged the free market theory by positing that it poses a lot of challenges to the proponents of globalisation, the neoclassical thinkers. The neoclassical school of thought holds that free trade without restrictions across boundaries is the best option to solve major economic challenges and serves as the lubricant to stimulate the frontiers of growth (Wan-Wen, n.d). That is, issues relating to lack of local expertise, products and services, development partners, and huge funds needed for gigantic capital projects will be contained in a globalised world, free trade and protectionism and financial restrictions. This implies that there will be flow of external investment, trade openness and free flow of labour across borders (which breed efficiency). This has the ability to reposition economically and technologically backward nations to the path of growth.

In this regard, after World War II, globalisation was wholly embraced by advanced nations first, and much later, followed by developing nations. This was highly necessitated on evidence, the failure of the command and control era before World War II. According to the neoclassical thinkers, globalisation came back stronger due to ease of doing business, low cost of movement (of goods, services and labour) and communication necessitate by new innovative technology that eased merchandise trade and the flow of capital resources across border. They also cited the establishment of General Agreement on Tariffs and Trade (GATT) in 1945 and later World Trade Organization (WTO) in 1995 as reasons for the emergence of globalisation.

The institution of the Bretton Woods institutions; whose focal agenda was to reflate the world economy to the path of growth after the Second World War also added another feather to the globalization. Obviously, this is understandable because money is the chief facilitator of transacts and every growth agenda. Prior to the use of various forms of money as a medium of exchange, trading of commodities was highly constrained due to the many disadvantages of the barter system, hence impeding economic activity. Consequently, colonies were at best operating in closed economic systems (autarchy) with subsistent production. Thus, the establishment of International Monetary Fund (IMF) and World Bank helped to solidify and establish a common denominator of transactions across borders. Consequently, these establishments championed the convergence of world markets, international settlement and propagated economic openness. For instance, as a precondition for all forms of assistance, developing nations was required to unbundle restrictive trade and finance policy (Palley, 2011). Specifically, developing nations like Nigeria were forced to adopt Structural Adjustment Program (SAP) in 1986 to unbundle government control and deregulate trade and the financial sector.

However, in the 5 years leading to the introduction of SAP in 1986, Nigeria's trade policies were designed inward to help protect infant industries by way of high tariffs, import licensing and quarterisation (Alum, 2016). Coupled with this era was when financial services were tightly regulated. For instance, the exchange rate (the dollar naira rate) was fixed. This essentially means that the pricing mechanism was not allowed to function freely. Thus, Nigeria was to an extent isolated economically and was eluded with the benefits of globalisation. 
The Nigerian experience in the face of globalisation is full with opportunities and threats. It afforded the nation international finance and transnational corporations to the real sector of the economy and other development partners. It has also facilitated free trade across border. This implies that Nigeria can import with little or tariff to meet her shortfall in production. Among others, it has also created huge markets for Nigerian manufacturing concerns. On the other hand, the Nigerian financial system and economy has been affected by various global financial crises due to the integration of world financial markets. It has also seen the death or stunted growth of infant industries due to intense competition from transnational corporations, "loss of cultural integrity, national economic autonomy is undermined or destroyed by open capital markets and flexible exchange rates" (Mutascu \& Fleischer, 2011). Among others, Nigeria has also lost funds to capital flight and manpower to brain drain.

Unsurprisingly, all these points are tenable for the rich and developed countries and more especially developing countries if they can fully maximize their strengths and the huge opportunities from globalization by minimize the risks and threats from trading with the world. Thus, this has sanctioned series of studies between globalization and economic growth. The importance of these studies are expedient as it would help validate (or not) the position of the neo-classical school of thought and other alternative thoughts most especially the noneconomists who have concerns for the costs and rewards of going global (Dreher, 2005). The findings from these studies are divergent, thus this study contributes to literature by observing current trends and the sector specific impact of foreign direct investments to agriculture and the productive subsector and trade openness on economic growth in Nigeria.

\subsection{Contemporary Issues}

The dominant theoretical axiom that globalization leads to economic growth in developing countries like Nigeria is highly questionable because the concerns that globalization raises the gap between the "haves and the have not's" (Awake, 2002) and more especially between developed and developing countries and between the elites and the lower class in developing countries are still there. In other words, the rich countries get richer while poor countries gets poorer, which is a textbook case of Matthew effect. This is even so as empirical results from studies are inconclusive on the growth stimulating premise of globalization in emerging countries like Nigeria. This does not in any way invalidate the impact of globalization on a country but this rather gives credence to the failure of most developing nations to create the necessary conditions to maximize the gains from international trade and capital inflow (Todaro \& Smith, 2006).

Consequently, the failure of Nigeria to capitalize on the enormous opportunities from globalization has made the country to have perpetual negative balance of trade and payments due to the excess of imports over exports. According to export-led growth strategists, the growth of an emerging nation is largely dependent on the capacity of the nation to produce goods and services in which they have comparative advantage for its local needs and ultimately for export, and import the produce in which they have comparative disadvantage (Nduka, Chukwu, Ugor \& Nwakaire, 2013).

Among other areas, Nigeria has good arable land for agriculture and raw materials for the manufacturing industry. However, until the discovery of crude oil in commercial quantity, the country has failed to maximize the enormous export earning potentials in these sectors. For instance, figures from the CBN Statistical Bulletin reports that the average manufacturing capacity utilization in the country to be $55.45 \%$ in $2008,56.76 \%$ in 2009 , and $56.82 \%$ in 2010 . The inability of the nation to produce massively to meet the huge markets for its products in the local and international markets also means that manufacturing concerns have not been able to 
capitalize on the economies of scale from large scale production. This is because wholesale production is cheaper than piece mail production. The reason for this is not farfetched - fixed production cost for research, advertisement, and product development are meagre for either small or large scale production. This makes the locally manufactured products to be more expensive. This invariably exacerbates Nigeria's import demand and over dependence on oil.

Notice that commodity prices like crude oil are highly volatile, thus its appreciation and or depreciation in price has a huge influence on the economic prospects of a country. It is therefore expected that in times of rising prices, the government and its agencies invest and carry out targeted diversification of the economy plus save for the rainy day. The logic behind this notion is that in times of falling prices economic activities declines, prices of goods and services increases as a result of imported inflation and people are downsized.

In addition, transnational corporations are highly sensitive to happenings in their host nations (more especially developing nations). The economic and political environments of developing nations are highly unstable (Waller-Hunter \& Jones, 2002) due to lack of continuity in economic policies at the inception of every new administration. For instance, the command and control economic policy of this administration made many foreign setups in the country to close down their operations. Thus, transnational corporations are always motivated to pull their investments and funds at every instance of contrived economic policies (Yaqub, Adam, \& Jimoh, 2013).

The intense rate of volatility and mobility of capital from developing countries always results in increase in consumer price index, interest rates, downsizing and declining aggregate demand, which altogether rendered their economies to be impotent and an unattractive investment destination (Obadan \& Obioma, 1999). For instance, Nigeria experienced three quarters of negative growth in 2016. Prior to the general elections in 2015, Nigeria was the number one foreign direct investments destination with the largest economy (in terms of GDP) in Africa. However, coupled with the political instability in the polity and the three quarters of negative growth (i.e. recession); Nigeria experienced massive exodus of transnational corporations and their investments.

It is also on record that a good percentage of external direct inflows do not effectively stimulating the growth of key sectors in the country (Ibrahim, n.d). According to economic theory, the real sector is the extraordinary accelerant of economic growth in a nation. Thus, any investment that does not stimulate the real productive sector enough would not lead to any meaningful output growth. In affirming this position, Olusanya (2013) stated that $60 \%$ of capital inflows are into the extractive industry (oil and gas subsector), and thus the remaining percentage is too small (Asiedu, 2003) to stimulate the other real sectors of the economy to grow. To this end, this study intends to reassess the impact of economic globalization on economic growth in Nigeria.

\section{Empirical Review}

There have been several empirical studies concerning the subject of this study; with divergent conclusions, thus giving room for researcher to further study the limitations of previous studies by adopting different methodologies, measurement variables, scope, modifying already existing models or calibrating new ones, all with the aim of building a robust knowledge base for informed economic decision making.

A recent study by Ojo (2018) focused on the impact of globalization on agriculture in Nigeria. To achieve this, the study made use of annual time series data covering 29 years for foreign direct investment (FDI) to agriculture, degree of openness, foreign exchange rate and consumer 
price index on agricultural output in Nigeria. The estimation was done using Error Correction Model and the results indicate that foreign exchange, degree of openness and foreign direct investment were not statistically significant in influencing agricultural productivity in Nigeria. However, consumer price index impacted positively on agricultural productivity to a larger extent. The study concluded that globalization has no significant impact on the growth of agriculture productivity in Nigeria.

Similarly, in another recent study by Idoko \& Taigai (2018) set out to ascertain the sector specific role on capital inflow to the manufacturing sector in Nigeria. The study found the existence of a long-run nexus between FDI and the manufacturing sector output growth in Nigeria. The study by Ogbokor (2018) investigated whether foreign direct investment affects economic growth in Namibia using quarterly from 1990 to 2014. The results found that there is a long run and direct relationship amongst the independent variables of foreign direct investment, exchange rage, trade openness on the independent variable of gross domestic product in Namibia.

The paper by Belloumi \& Alshehry (2018) investigated the causal links between domestic capital investment, foreign direct investment (FDI), and economic growth in Saudi Arabia over the period 1970 to 2015, using the autoregressive distributed lag (ARDL) bounds testing to cointegration approach. The fully modified ordinary least squares (FMOLS), dynamic ordinary least squares (DOLS), and the canonical co-integrating regression (CCR) were employed to check the robustness of the ARDL long run estimates. The results show that in the long term there are negative bidirectional causality between non-oil GDP growth and FDI, negative bidirectional causality between non-oil GDP growth and domestic capital investment, and bidirectional causality between FDI and domestic capital investment. FDI affects negatively domestic capital investment in the short run, whereas domestic capital investment affects negatively FDI in the long run. Both finance development and trade openness affect positively non-oil GDP growth, FDI inflows and domestic capital investment in the long run.

Afolabi, Danladi, \& Azeez (2017) studied the nexus between foreign trade and economic growth and the factors determining output growth in Nigeria. To achieve this, ordinary least squares was used and the results reported that government expenditures, interest rate, import and export are all positively significant while exchange rate and foreign direct investment are negatively insignificant to the growth process of the Nigerian Economy.

Similarly, Abiodun (2017), in his award winning paper examined the nexus between trading with the world and output growth in Nigeria. Export volumes, import volumes, trade openness, gross capital formation and exchange rate were used as the predictor variable while real gross domestic variable was used as the measure for economic. The results showed that the explanatory variables have a positive and significant relationship with economic growth in Nigeria.

Lawal \& Ezeuchenne (2017) studied to determine the impact of world-wide trade on the economic growth in Nigeria. The study used time series data from 1985 to 2015 on imports, exports, balance of trade and trade openness as proxy for foreign trade and real gross domestic product as a measure for economic growth in Nigeria. Co-integration and Vector Error Correction Model (VECM) was employed to analyse the series. The result reported along run relationship between foreign trade and economic growth. More specifically, import and trade openness are both insignificant in the short run but significant in the long run while export and balance of trade are significant in both the short and long run. The granger causality test showed that economic growth is independent of imports, exports and balance of trade but economic growth is unidirectional with trade openness. 
In another country specific study (Stephen \& Obah, 2017), studied the influence of foreign trade on economic growth in Nigeria from 1981 to 2015. Numeric values for the study was obtained from the CBN statistical bulletin for gross domestic product, non-oil imports, oil imports, nonoil exports, and oil exports. Gross domestic product was regressed on non-oil imports, oil imports, non-oil exports, and oil exports. The results reported as follows; oil imports have a statistically insignificant impact on output, while non-oil import has a statistically significant influence on output. Oil export reported a linear and significant impact on output whereas nonoil export showed a nonlinear and significant relationship with output in Nigeria. In all, the study suggested that international trade has a positive impact on economic growth in Nigeria.

(Moyo, Kolisi, \& Khobai, 2017) seek to ascertain the long run relationship between trade openness and economic growth in Ghana and Nigeria from 1980 to 2016. This study purposed to determine the long run relationship between trade openness and economic growth in Ghana and Nigeria covering the period between 1980 and 2016. The Autoregressive distributed lag (ARDL) model was employed in this study to study the long run relationship between the variables of gross domestic product, trade, investment, exchange rate and inflation. The findings of the study suggested existence of a long run relationship among the variables for both countries. The results further showed that trade openness has a positive impact on economic growth and significant at a single percentage point in Ghana while in Nigeria trade openness has a negative and insignificant impact on economic growth.

In another recent study by Markjackson, Johnny, \& Siaisiai (2018), which set out to examined the influence of foreign trade on economic growth in Nigeria found that oil import has a linear but insignificant impact on real gross domestic product in Nigeria, non-oil imports and non-oil exports has a positive and significant impact on economic growth in Nigeria, oil exports has a nonlinear and insignificant impact on real gross domestic product in Nigeria. In all, the study is of the affirmative on the nexus and impact of trade openness on economic growth in Nigeria.

Alimi \& Atanda (2011) investigated the effect of globalisation on economic growth in Nigeria between 1970 and 2010 amidst cyclical fluctuations in foreign investment. They employed autoregressive model the analyses revealed that globalisation has positive and significant effect on economic growth in Nigeria, while the positive of business cycle on real output growth was insignificant. The study concluded that globalisation and cyclical movement in foreign investment have significantly enhanced economic growth in Nigeria.

The study observes the challenges aggregate data of foreign direct investments to the private sector and elected to use disaggregate time series data to select sectors. The problem with aggregate data is that it assumes homogeneity - that is it assumes all the sectors that make up the private sector to be similar or the same. This has the tendency of creating error of aggregation due to the fact that all the sectors have their distinctive features that are different from each other. This means results from such studies would not give an accurate picture of the link and effect relationship (Thomas, 2002) between the study variables. We intend to correct this error by using disaggregate data (i.e. sector specific data) to ascertain the impact of the study elements.

\section{Research Design}

Research design is the overall strategy that is used in integrating the different components of the study in a coherent and logical manner, thereby, giving room to address the major concerns as well as the attainment of the objectives of the study. Consequently, to ascertain the impact of the components of foreign direct investments and the degree of trade openness on economic growth in Nigeria, secondary annual time series data was collated and used for the analyses 
and estimation. It is assumed that time series data at level is not stationary, thus, the dataset was first and foremost solidified to avoid spurious results before estimation.

The ex-post facto research design was employed to examine how the independent variables affect the dependent variable. Ex-post facto research design is a quasi-experimental design used in examining how an independent variable affects a dependent variable in retrospect. Consequently, this research design was adopted due to the fact that researcher has no control over the behaviour and numeric values of the variables of the study. Thus, this design enabled the researcher to collate data and use econometric techniques to observe and coagulate the series, ascertain the long run nexus and estimate the direction and magnitude of the independent variables on the dependent variable of the study.

\subsection{Model Specification Process}

The model for this study is built following the AK growth model advanced by Rebelo (1991). The model is expressed as follows:

$Y=A K_{t}$

Where $\mathrm{Y}, \mathrm{A}$, and $\mathrm{K}$ denotes output, technological advancement and capital respectively. The model expresses output as a direct product of capital stock.

This theoretical framework is slightly modified to capture the sector specific impact of foreign direct investment to the manufacturing and agriculture subsectors and the degree of trade openness. The central hypothesis behind this reasoning is hinged on the supposition that developing nations and indeed the real private sector of these countries are constrained of funds and thus capital inflow can stimulate the productive capacity of the nation, and hence trading with the rest of the world.

Therefore national output is a function of changes in foreign direct investments to the manufacturing and agriculture subsectors and trade openness (measured by the degree of trade openness, which is total trade divided by gross domestic product). The modified functional model is expressed as follows;

$R G D P=F\left(F D I_{M A N}, F D I_{A G}, D T O\right)$

This is mathematically expressed as follows;

$R G D P=b_{0}+b_{1} F D I_{M A N}+b_{2} F D I_{A G}+b_{3} D T O$

The disturbance term (e) is introduced to capture changes in the dependent variable that could not be explained by the explanatory variables in the model. Thus the model is expressed econometrically as follows:

$L n R G D P_{t}=b_{0}+b_{1} \operatorname{LnFDIMAN} t+b_{2} \operatorname{Ln} \mathrm{FDIAG}_{\mathrm{t}}+b_{3} D T O+e_{t}$

Note: if equation (4) above produces any long run equilibrium relationship, there is an econometric ground to carry out the error correction process. Following finance literature, the Engle-Granger Representative Theorem of Error Correction of 1987 was employed to determine the direction and magnitude of the measures of the study. The Engle-Granger approach was employed because the method put forward the use of ordinary least square estimators in estimating the functional relationships, test of stationarity and co-integration that lays the foundation for error correction (Ogege \& Boloupremo, 2014). Thus, the error correction model is stated below;

$\Delta L n R G D P_{t}=b_{0}+\sum b_{1} \Delta L n F D I_{\mathrm{MAN} t-i}+\sum b_{2} \Delta L n F D I_{\mathrm{AG} t-i}+\sum b_{3} \Delta L n D T O_{t-i}-\alpha E C_{t-i}+e_{i}$ 
Where; $b_{0}$ is the intercept, $b_{1}-b_{3}$ are the coefficients of the explanatory variables, $L n$ is natural logarithm, which is used to check the effect of co-movement in the explanatory variables, RGDP is Real Gross Domestic Product - a measure for national output growth, FDIman is Foreign Direct Investments to the manufacturing sector, FDI ${ }_{\mathrm{AG}}$ is Foreign Direct Investments to the agriculture sector, DTO is the degree for trade openness - a measure for trade openness, e is the disturbances term - Sweeney, William \& Anderson (2006) states that the error term capture changes in the dependent variable that cannot be explained by the linear effect of all the independent variables in the model. Finally, EC = Error correction term. The $\alpha$ (coefficient) of the error correction term predicts the speed of adjustment to an equilibrium position. Note; if the coefficient bears a negative sign, then the model is moving towards equilibrium. However, if the sign is positive, then the model is moving away from equilibrium. Economic theory presumes the sign to always be negative.

\section{A priori Expectation}

$b_{1}>0, b_{2}>0, b_{3}>0$

This means (1) every increase in capital inflow to the manufacturing and agriculture sectors leads to an increase in national output. (This means that FDI has a direct relationship with economic growth), (2) free trade between countries leads to national output growth. (This means trade openness has a positive relationship with economic growth). The economic reason behind this axiom is that as nations engage in trade with each other based on their comparative advantages, the more they have the tendency to grow.

\subsection{Description of the Variables}

The dependent variable used is real gross domestic product. This measure serves as the barometer for gauging the real rate of economic growth of a country. This variable is preferred because captures the actual value of the national transactions of a country. The independent variables included in thec model are foreign direct investment and the degree of trade openness. These measures have been severally used in literature (See Dreher, 2005; Muibi, 2010; Javid \& Qayyum 2011; Kargbo, 2012; Ojo, 2018; Ogbokor, 2018; and Idoko \& Taiga, 2018).

1. Foreign Direct Investment: this is also known as international finance or capital inflow. Like the name implies foreign direct investments are funds channeled to sectors of a domestic economy with the prospect of making adequate returns. This implies that foreign direct investment to agriculture and the manufacturing sectors are capital investments from foreign nations due to the potential of making high returns on investment. A raising national output level suggests a brighter prospect for international capital inflow to Nigeria. Since capital inflow informs the robustness of the recipient economy, foreign direct investment in the long run would accentuate the productivity. The choice of foreign direct investment as a measure for economic globalization is due to the fact the integration of the world financial markets has as a consequence increased the flow of capital across national boundaries. In addition, foreign capital is considered by many countries (especially developing ones) as a major source of extra fund needed to stimulate economic growth.

2. Degree of trade openness: The rate of economic openness of a country is generally calculated as the proportion of total merchandise trade to national output. The economic openness of a country increases foreign currency revenues and expenditures as the export and import volume increases or decreases. The inclusion of the trade policy variable in the equation is to investigate the well documented argument in literature that trade, may increase competition, permit the realization of comparative advantage, enable countries to purchase goods from abroad, and provide opportunities to gain access to new technology as well as managerial skills. Thus, the degree of trade openness is expected to have a positive coefficient. 


\section{Econometric Results}

\subsection{Descriptive Statistics}

Descriptive statistics is used to describe the basic characteristics of the data series used in the analyses. The summary results of the descriptive statistics are presented in table 4.1.

Table 4.1: Summary Descriptive Statistics

\begin{tabular}{lcccc}
\hline & DTO & FDIAG & FDIMAN & RGDP \\
Mean & 0.312059 & 2.981824 & 68.10591 & 30.01206 \\
Median & 0.350000 & 1.209000 & 32.90055 & 22.05500 \\
Maximum & 0.590000 & 14.12830 & 219.5120 & 67.15000 \\
Minimum & 0.070000 & 0.117300 & 1.705700 & 13.77000 \\
Std. Dev. & 0.130472 & 4.814731 & 77.92575 & 16.45552 \\
Skewness & -0.223536 & 1.669495 & 0.825239 & 0.905548 \\
Kurtosis & 2.377047 & 3.893396 & 1.958470 & 2.433490 \\
Jarque-Bera & 0.832921 & 16.92492 & 5.395892 & 5.101416 \\
Probability & 0.659377 & 0.910211 & 0.167344 & 0.378026 \\
Sum & 10.61000 & 101.3820 & 2315.601 & 1020.410 \\
Sum Sq. Dev. & 0.561756 & 764.9939 & 200389.9 & 8935.876 \\
Observations & 34 & 34 & 34 & 34 \\
\hline
\end{tabular}

The total number of observations is 34 . This is indicative that there is no missing value in the considered time period. The average growth rates for the variables are: degree of trade openness (0.312059), foreign direct investments to the agriculture sector (2.981824), foreign direct investments to the manufacturing sector (68.10591), and real gross domestic product (30.01206). The Jarque-Bera statistics specifies that none of the variables departed from normality, thus, the variables are considered to have a normal distribution. All the variables are positively skewed with the exception of the degree of trade openness.

The variability in the distributions is captured by the standard deviation. The results report the following; degree of trade openness (0.130472), foreign direct investments to the agriculture sector (4.814731), foreign direct investments to the manufacturing sector (77.92575), and real gross domestic product (16.45552). The values for degree of trade openness and real gross domestic product are noticeably dispersed around the centre and below the mean values, which indicate there are no wide variations among the data over the years in each distribution. However, the values for foreign direct investments are above their respective mean and the middle values; this is indicative of a benign wide variation.

\section{2 . Augmented Dickey Fuller (ADF) Unit Root Test}

The Augmented Dickey Fuller unit root test was employed to solidify the numeric values of the variables and set the tune for co-integration and error correction. Considering two different series A and B, if both are stationary at level I (0), it gives impetus to regress the series. However, if their levels of integrated are different, for instance one being in its first difference I (1) and the other being at it level I (0), one has to transform the model. The least square technique can only be called to bear when the variables are all integrated in the same order. The unit root test results are presented in table 4.2.

Table 4.2: Summary Augmented Dickey Fuller Test Results

\begin{tabular}{cccc}
\hline Variables & ADF Statistics & t-statistics @ 5\% & Decision \\
FDI (ag) & -6.099326 & -3.557759 & $\mathrm{I}(1)$ \\
FDI(man) & -4.578945 & -3.557759 & $\mathrm{I}(1)$ \\
DTO & -5.242963 & -3.557796 & $\mathrm{I}(1)$ \\
RGDP & -5.204981 & -3.548490 & $\mathrm{I}(1)$ \\
\hline
\end{tabular}


The table shows the summary of the unit root test for the variables used in the study. The rule of thumb for this test states that a variable is integrated when the ADF statistics is greater than the $t$-statistics at the chosen level of significance (simply put, ADF Statistics $>t$-statistics). The results shows that all the variables used in the model are all integrated at first difference, symbolized by I(1), all at 5 percent significance level. This means that the series have been solidified and hence avoiding spurious regression results for the estimates of the model of the study.

The justification for a co-integration test is that the variables have to be integrated. Since all the variables are integrated at their first differencing we move ahead to run the co-integration test and the error correction mechanism.

\subsection{Co-integration Test Results}

The Johansen multivariate co-integration Trace and Maximum Eigenvalue test results are presented in tables 4.3 and 4.4 .

Table 4.3: Unrestricted Co-integration Rank Test (Trace)

Sample (adjusted): 19832014

Included observations: 32 after adjustments

Trend assumption: Linear deterministic trend (restricted)

Series: RGDP DTO FDIAG FDIMAN

Lags interval (in first differences): 1 to 1

Unrestricted Co-integration Rank Test (Trace)

\begin{tabular}{|c|c|c|c|c|}
\hline $\begin{array}{l}\text { Hypothesized } \\
\text { No. of } C E(s)\end{array}$ & Eigenvalue & $\begin{array}{l}\text { Trace } \\
\text { Statistic }\end{array}$ & $\begin{array}{c}0.05 \\
\text { Critical Value }\end{array}$ & Prob.** \\
\hline None* & 0.758902 & 89.81065 & 63.87610 & 0.0001 \\
\hline At most $1^{*}$ & 0.501397 & 44.28902 & 42.91525 & 0.0362 \\
\hline At most 2 & 0.408145 & 22.01876 & 25.87211 & 0.1402 \\
\hline At most 3 & 0.150913 & 5.234978 & 12.51798 & 0.5630 \\
\hline
\end{tabular}

Trace test indicates 2 co-integrating eqn(s) at the 0.05 level

* denotes rejection of the hypothesis at the 0.05 level

**MacKinnon-Haug-Michelis (1999) p-values

Table 4.4: Unrestricted Co-integration Rank Test (Maximum Eigenvalue)

\begin{tabular}{ccccc}
\hline \hline $\begin{array}{c}\text { Hypothesized } \\
\text { No. of CE(s) }\end{array}$ & Eigenvalue & $\begin{array}{c}\text { Max-Eigen } \\
\text { Statistic }\end{array}$ & $\begin{array}{c}0.05 \\
\text { Critical Value }\end{array}$ & Prob. $^{* *}$ \\
\hline \hline None* & 0.758902 & 45.52163 & 32.11832 & 0.0007 \\
At most 1 & 0.501397 & 22.27026 & 25.82321 & 0.1376 \\
At most 2 & 0.408145 & 16.78378 & 19.38704 & 0.1148 \\
At most 3 & 0.150913 & 5.234978 & 12.51798 & 0.5630 \\
\hline \hline
\end{tabular}

Max-eigenvalue test indicates 1 co-integrating eqn(s) at the 0.05 level

* denotes rejection of the hypothesis at the 0.05 level

**MacKinnon-Haug-Michelis (1999) p-values

Tables 4.3 and 4.4 shows the Johansen unrestricted co-integration rank test results for Trace and Maximum Eigenvalue. The rule of thumb for this test is for the trace statistic and Max-Eigen statistic values to be greater than the critical values at the 5 percent level. 
The results indicate the existence of long run relationship in the calibrated model for the study. Specifically, the trace statistics from table 4.2 reported the existence of 2 co-integrating long run relationship at 5 percent level of significance; hence, this implies that there is the possibility of a long run equilibrium relationship between the variables used in the model. Similarly, the Maximum Eigenvalue also reported a single co-integrating equation (s) at the 0.05 level. This invariably invalids the no long run relationship hypothesis and gives the econometric ground to go ahead with the error correction process.

\subsection{Error Correction Mechanism (ECM) Test}

The Error Correction Mechanism (ECM) was adopted following the least square example to estimate and determine the impact of the explanatory variables (foreign direct investment to the manufacturing and agriculture sub-sectors) and the degree of trade openness on the dependent variable (real gross domestic product)

To avoid spurious results, the estimation was done using the solidified data. That is, the procedure observed the order of integration of the variables which was in there first difference. The empirical results from the model were used to test the null hypotheses raised for the study. The results are presented in table 4.5.

Table 4.5: Impact of Foreign Direct Investments to the Manufacturing \& Agriculture Subsectors and the Degree of Trade Openness on Real Gross Domestic Product in Nigeria.

Dependent Variable: RGDP

Method: Least Squares technique

Sample (adjusted): 19832014

Included observations: 32 after adjustments

\begin{tabular}{lrlll}
\hline \hline \multicolumn{1}{c}{ Variable } & Coefficient & Std. Error & t-Statistic & Prob. \\
\hline \hline FDIMAN & 0.129174 & 0.025835 & 4.999936 & 0.0000 \\
FDIAG & 1.512117 & 0.400427 & 3.776262 & 0.0008 \\
DTO & 46.27236 & 5.021745 & 9.214398 & 0.0000 \\
ECM(-1) & -0.607621 & 0.21001 & -2.893254 & 0.9878 \\
\hline \hline R-squared & 0.851866 & Mean dependent var & 30.94313 \\
Adjusted R-squared & 0.835995 & S.D. dependent var & 16.52394 \\
S.E. of regression & 6.691786 & Akaike info criterion & 6.756107 \\
Sum squared resid & 1253.840 & Schwarz criterion & 6.939324 \\
Log likelihood & -104.0977 & F-statistic & 239.5497 \\
Durbin-Watson stat & 0.707897 & Prob(F-statistic) & 0.009010 \\
\hline \hline
\end{tabular}

Table 4.5 x-rays the impact of the explanatory variables (foreign direct investment to the manufacturing and agriculture sub-sectors and the degree of trade openness on the dependent variable, real gross domestic product in Nigeria.

The ECM term of -0.607621 indicate that ECM $(-1)$ is well specified and the diagnostic statistics are good. The negative sign depicts the short run adjustment of the variables to the dependent variable. The ECM term also report that approximately $61 \%$ fast speed of adjustment towards equilibrium. This implies that $61 \%$ of disequilibrium caused by exogenous shocks or short run fluctuations in the previous period was corrected in the current period. 
It also emerge that the adjusted coefficient of determination $\left(\mathrm{R}^{2}\right)$ explained the dependent variable, real gross domestic product by 0.835995 . Specifically, this implies that approximately $84 \%$ of real gross domestic product growth in Nigeria is explained by foreign direct investment to the manufacturing and agriculture sub-sectors and the degree of trade openness respectively. The test for the overall significance of the model shows that the model is statistically significant because the F-statistics value of 239.5497 is greater than the probability value, which is statistically zero.

Furthermore, the a priori expectation of the coefficients of the variables turned out as expected. Specifically, the results show that foreign direct investment to agriculture (FDIag) has a positive relationship with real gross domestic product in Nigeria. The impact of the nexus is statistically significant at the 5\% significant level. Similarly, capital inflow to the manufacturing sector (FDIman) reported a linear relationship with real gross domestic product. The magnitude of the impact is statistically significant at the $5 \%$ significant level.

The results for the degree of trade openness specifically reported a positive coefficient value (46.27236). It also emerged that the variable has a statistically significant relationship with real gross domestic product in Nigeria.

\section{Discussion of Findings}

The empirical findings of this study affirm that there is a significant relationship between economic globalisation and economic growth in Nigeria. This invalidates the concerns that globalization raises the gap between the "haves and the have not's" in developing countries (Awake, 2002). It rather affords developing nations opportunities to easily access to funds from foreign investors and transnational corporations to the real sector of the economy plus free trade across borders.

The direction and the magnitude of the coefficients of the determinants are similar. Specifically, it emerged that foreign direct investments to the agriculture sub-sector has a positive impact on real gross domestic product in Nigeria. This means that 100 dollar increase in foreign direct investments to business ventures in the agricultural sector improves national output by 151 units. The findings also show that the impact of capital flows to agriculture has a significant role in enhancing the economic growth of the country. This in effect gives credence to the long held position that agriculture, as it was the case before the discovery of oil has the capacity to grow and even be one of the major source of foreign exchange earner for Nigeria. It is imperative to affirm that foreign portfolio investments is a major driver of economic growth in Nigeria. Although capital inflow to agriculture has the capacity to enhance output as a result of the linear relationship it has with real gross domestic, the sector is perceived by investors as a highrisk market for investment (Olokoyo, 2012), thus measured policies must be instituted to ensure its sustainability. Thus protectionist policy measures are not desirable as was the case prior to the adoption of the structural adjustment programme. The goal of which was to improve the country foreign investment climate by eliminating trade and investment regulations, boost foreign exchange earnings by promoting exports, improve production base, reduce government deficits through cuts in spending and to promote economic growth. The findings on this variable are contrary to the conclusion drawn by Ojo (2018), who affirmed in his study that there is no linear and significant impact between capital inflow and output growth in Nigeria.

Similarly, it also emerged that capital inflow to manufacturing concerns holds a positive and direct impact on real gross domestic product in Nigeria. This implies that every increase in the investment of foreign nationals in the manufacturing sector has the potential to enhance real gross domestic product in Nigeria. The results specifically show that FDI to the manufacturing sector enhance the productive capacity of the nation by 13 units. The results further show that 
the magnitude of the impact is statistically significant. This shows that foreign direct investments play a crucial role in the manufacturing sector which has fashioned out potential benefits which has spurred economic activities and thus, economic growth by providing additional capital to Nigeria. Foreign direct investment is therefore supplement to domestic funds which helps in the acquisition of equipment and machinery used in the production process and thus the productive capacity of the country. However, economic volatility and change in government has the propensity to encourage divestment especially by foreign investors. For instance, the command and control economic policy of this administration made many foreign operations in the country to close down their operations.

Although theoretical conjecture by Olusanya (2013) posits that capital inflow to the real sector is inadequate. According to him, $60 \%$ of foreign direct investments are channelled into into the oil and gas subsector alone, and that the remainder is too benign (Asiedu, 2003) to accentuate real and impactful growth in other sectors. This study holds that foreign direct investments to the productive sector contribute positively national output growth in Nigeria.

The findings on the degree of trade openness has a similar nexus result established in a country specific study by Markjackson, Johnny, \& Siaisiai (2018). Specifically, it emerged that the degree of trade openness has positive and significant impact on economic growth in Nigeria. Conversely, the institution of restrictive trade policies is not desirable.

The findings further averred that as the degree of trade openness increase so does its contribute positively to economic growth in Nigeria. This implies that economic openness has enhanced the economic performance of the Nigerian economy. This is so because trade openness increased competition, permit the realization of comparative advantage, enable countries to purchase goods from abroad, and provide opportunities to gain access to new technology as well as managerial skills. The result specifically report that every one percent change in the degree of trade openness leads to 46.27236 unit in gross domestic product growth in Nigeria. The findings on this variable are similar to the findings of Azeez, Dada, \& Aluko (2014). Generally, the findings follow closely to what economic theory would have suggested; that is, trading with the world and capital inflows has the capacity to grow the local economy.

\section{Summary \& Conclusion}

The examined the impact of economic globalization on economic growth in Nigeria. This was aimed at ascertaining the generally acclaimed theoretical position that economic globalization (through capital inflow and trade openness anchored by financial integration and trade liberalization) enhances economic growth in emerging economies. Consequently, a robust model was built to achieve this purpose.

It emerged that capital inflow to the manufacturing and agriculture sector and degree of trade openness have a positive impact on real gross domestic product in Nigeria. The findings also suggested that the level of the impact is significant. Consequent on these, the study conclude that economic globalization has a direct significant impact on economic growth in Nigeria. The study, therefore, lends further credence to the plethora of suggestion that economic globalization contributes to economic growth. This is particularly so in the case of Nigeria. The following recommendations are made;

1. Measures should be taken to ensure stability in the polity to circumvent socio-political and economic volatility. This will help contain the incessant capital mobility and divestment from the country. 
2. The managers of the economy should put in place the necessary infrastructure to set the pace for a revolution in the agriculture sector, which was a major foreign exchange earner prior to the discovery of crude oil. Measures should also be targeted at investment sustainability.

3. Economic reforms should be aimed at encouraging production of goods that, the nation has comparative and competitive advantage over its trading partners and the export of final goods rather than raw materials. This has the capacity to place Nigeria in a good pedestal to have significant returns from transnational trade.

\section{References}

Abiodun, K. (2017). Contribution of international trade to economic growth in Nigeria. Eastern Illinois University, the Keep.

Afolabi, B., Danladi, J. D., \& Azeez, M. I. (2017). International trade and economic growth in Nigeria. Global Journal of Human-Social Science, 17(5), 28-39.

Alimi, O. Y., \& Atanda, A. A. (2011). Globalization, business cycle and economic growth in Nigeria. African Journal of Scientific Review, 7(1), 344-357.

Asiedu, E. (2001). On the determinants of foreign direct investment to development countries: is Africa different? World Development, 30(1), 107-119.

Asiedu, E. (2003). Capital controls and foreign direct investment. World Development, 32(3), $479-490$.

Awake (2002). Globalisation: Curse or Cure. Journal of Awake. May 22, 1-14.

Azeez, B. A., Dada, S. O., \& Aluko, O. A. (2014). Effect of international trade on Nigerian economic growth: the $21^{\text {st }}$ century experience. International Journal of Economics, Commerce and Management United Kingdom, II(10), 1-8.

Central Bank Statistical Bulletin, 2016.

Dreher, A. (2005). Does globalization affect growth? Evidence from a new index of globalization. Research Paper Series Thurgauer Wirtschaftsinstitut, 6, 1-32.

Ibrahim, M. (n.d). The effect of globalisation on the development of underdeveloped economies.

Idoko, C. U., \& Taiga, U. U. (2018). Effect of foreign direct investment (FDI) on manufacturing output in Nigeria (1981 - 2016). Advances in Social Sciences Research Journal, 5(5) 181-197. Doi:10.14738/Assrj.55.4319.

Kilic, C. (2015). Effects of globalization on economic growth: Panel data analysis for developing countries. Economic Insights - Trends and Challenges, IV(LXVII), 1-11

Lawal, E. O. \& Ezeuchenne, K. (2017). International trade and economic growth in Nigeria. Journal of Humanities and Social Science, 6(8), 35-43. DOI: 10.9790/08372206083543

Markjackson, D., Johnny, N., \& Siaisiai, S. T. (2018). Foreign trade and its impact on economic growth in Nigeria. International Journal of Economics, Commerce and Management, VI(4), $748-761$.

Moyo, C., Kolisi, N. \& Khobai, H. (2017). The relationship between trade openness and economic growth: The case of Ghana and Nigeria. Munich Personal RePEc Archive, MPRA Paper No.81317. Retrieved from https://mpra.ub.unimuenchen.de/81317/ 
Nduka, E. K., Chukwu, J. I., Ugbor, K. I., \& Nwakaire, O. N. (2013). Trade openness and economic growth: A comparative analysis of the pre and post structural adjustment programme (sap) periods in Nigeria. Asian Journal of Business and Economics, 3(3.4), 1-12.

Obadan, M. I., \& Obioma, E. C. (1999). Contemporary issues in global trade and finance and their implications. Journal of Economic Management, 6, 1-40.

Ogbokor, C. O. (2018). Foreign direct investment and economic progress: Application of a dynamic model. International Journal of Economics and Finance Studies, 10(1), 1 - 15.

Ogege, S., \& Boloupremo, T. (2014). Deposit money banks and economic growth in Nigeria. Financial Assets and Investing, 1(1).

Ojo, A. S. (2018). Globalization and agricultural productivity paradigm: The Nigeria perspective. Archives of Business Research, 6(1), 94-104. Doi: 10.14738/abr.61.4022.

Olokoyo, F. O. (2012). Foreign direct investment and economic growth: A case of Nigeria. Bvimsr's Journal of Management Research, 4(1), 1-30.

Olusanya, S. O. (2013). Impact of foreign direct investment inflow on economic growth in a pre and post deregulated Nigeria economy. A granger causality test (1970-2010). European Scientific Journal, 9(25), 336-356.

Palley, T. I. (2011). The Rise and Fall of Export-led Growth. Levy Economics Institute Working Paper No. 675, 1-24.

Porter, M. E (1985). Competitive Advantage: Creating and sustaining superior performance, free press.

Rebelo, S. (1991). Long-run policy analysis and long-run growth. Journal of Political Economy, 99, 500-521.

Stephen, S. A. \& Obah, D. O. (2017). The impact of international trade on economic growth in Nigeria: An econometric analysis. Asian Finance \& Banking Review, 1(1), 28-47.

Sweeney, D. C., Williams, T. A., \& Anderson, D. R. (2006). Fundamentals of Business Statistics: International Students Edition. Thomson, South-Western.

Thomas, A. G. (2002). Aggregate vs. disaggregated data in regression analysis: implication for inference. Federal Reserve Bank of St. Louis, Research Division, working Paper 2002024B, 1-8. Retrieved from: http://research.stlouisfed.org/wp/2002/2002-024.pdf.

Todaro, M. P. \& Smith, S. C. (2006). Economic Development (9th ed.). England: Pearson Education Ltd.

Waller-Hunter, J., \& Jones, T. (2002). Globalization and sustainable development. International Review for Environmental Strategies, 3(1), 53-62.

Wan-Wen, C. (n.d). Globalization and economic development. Taiwan Social Studies Quarterly, 42(2), 263-239.

Yaqub, J. O., Adam, S. L., \& Jimoh, A. (2013). Foreign direct investment and economic growth in Nigeria: An empirical analysis. American Academic \& Scholarly Research Journal, 5(1), 74-82. Retrieved from www.aasrc.org/aasrj 